\title{
Analisis Pembelajaran Daring di SD 2 Tenggeles Mejobo Kudus pada Masa Pandemi Covid-19
}

\author{
Muhammad Kartika $^{1]}$, Erik Aditia Ismaya ${ }^{2]}$, Muhammad Noor Ahsin ${ }^{3]}$ \\ Universitas Muria Kudus \\ E-mail: ${ }^{1}$ kajikartika@gmail.com \\ 2erikaditia@umk.ac.id \\ 3noor.ahsin@umk.ac.id
}

\begin{abstract}
Abstrak
Latar belakang dilakukannya penelitian ini adalah melihat dari latar belakang kendala pembelajaran daring yang dialami oleh siswa dan guru dalam melakukan pembelajaran daring selama pandemi Covid-19 di SD 2 Tenggeles. Penelitian ini bertujuan mendeskripsikan kendala pembelajaran daring yang dialami oleh siswa dan guru, dan mendeskripsikan solusi kendala pembelajaran daring di SD 2 Tenggeles pada masa pandemi Covid-19. Metode penelitian yang digunakan dalam penelitian ini adalah Kualitatif Deskriptif. Teknik pengumpulan data yang digunakan adalah dokumentasi, observasi dan wawancara. Hasil penelitian menunjukkan beberapa kendala yang dialami oleh siswa yaitu siswa merasa jenuh karena selalu belajar di rumah, siswa tidak pernah bertemu untuk belajar dengan temannya dan siswa merasa kurang paham dalam memahami materi pelajaran. Selain itu kendala yang dialami guru adalah guru merasa pembelajan kurang maksimal kerena guru tidak bisa menyampaikan meteri secara tatap muka dan guru tidak bisa melihat perkembangan siswa dalam menguasai materi pelajaran. Solusi dari kendala yang dialami oleh siswa adalah orang tua selain mengasuh dan menemani anak dalam belajar diharapkan juga menggantikan peran guru untuk mengajari anak dalam memahami materi pelajaran yang sulit dan siswa diharapkan untuk bisa belajar kelompok dengan teman agar tidak jenuh dalam belajar di rumah. Lalu solusi dari kendala yang di alami oleh guru adalah guru dapat menghimbau orang tua untuk membiarkan anak mengerjakan soal evaluasi agar dapat melihat kemampuan anak dalam menguasai materi pelajaran. Berdasarkan kendala yang dialami oleh guru dan siswa solusi dari permasalahan tersebut adalah melakukan pembelajaran berbasis Blended Learning atau pembelajaran yang mengkombinasikan pembelajaran tatap muka dengan pembelajaran berbasis komputer.
\end{abstract}

Kata Kunci: Covid-19, Kendala, Pembelajaran Daring.

\section{Analysis of Online Learning in SD 2 Tenggeles Mejobo Kudus during Pandemic Covid-19}

\section{Abstract}

Background of this research is to know the problem of the background during online learning constraints experienced by students and teachers in doing online learning during the pandemic in SD 2 Tenggeles. This research aims to describe the online learning constraints experienced by students and teachers, and describe the solutions to online learning problems at SD 2 Tenggeles during the Covid-19 pandemic. The research method 
used in this research is descriptive qualitative. The data collection techniques used were documentation, observation and interviews. The results showed several obstacles experienced by students, namely students feeling bored because they always studied at home, students never met to study with their friends and students felt they did not understand the subject matter. In addition, the obstacles experienced by the teacher were that the teacher felt that their learning was not optimal because the teacher could not convey material faceto-face and the teacher could not see the development of students in mastering the subject matter.The solution to the problems experienced by students is that parents besides caring for and accompanying children in learning are expected to also replace the role of the teacher to teach children to understand difficult subject matter and students are expected to be able to study in groups with friends so as not to be bored with learning at home. Then the solution to the problems experienced by the teacher is that the teacher can urge parents to let the child work on evaluation questions in order to see the child's ability to master the subject matter. Based on the obstacles experienced by teachers and students, the solution to these problems is to carry out Blanded Learning-based learning or learning that combines face-to-face learning with computer-based.

Keywords: Covid-19, Problem, Online Learning

\section{PENDAHULUAN}

Pendidikan adalah hal penting dalam kehidupan manusia dengan pendidikan manusia akan mempunyai budi pekerti dan akhlak yang baik tahu benar dan salah. Khadir (2012: 8) menyatakan bahwa Pendidikan tidak pernah lepas dari manusia dan selalu berpusat pada manusia dan kehidupannya, baik sebagai subjek maupun objek. Tiada pendidikan tanpa manusia dan tiada manusia tanpa pendidikan, hubungan manusia dengan pendidikan ini bersifat simbiosis, manusia mengembangkan pendidikan dan pendidikan mengembangkan manusa dan kehidupannya. Menurut UU RI No. 20 Tahun 2003 tentang Sistem pendidikan Nasional dalam Bab 1 Pasal 1 ayat 1 menyatakan bahwa Pendidikan adalah usaha sadar dan terencana untuk mewujudkan suasana belajar dalam proses pembelajaran agar peserta didik secara aktif mengembangkan potensi dirinya untuk memiliki kekuatan spiritual keagamaan, pengendalian diri, kepribadian, kecerdasan, akhlak mulia, serta keterampilan yang diperlukan dirinya, masyarakat, bangsa dan negara. Dan ayat 15 pendidkan jarak jauh adalah pendidikan yang peserta didiknya terpisah dari pendidik dan pembelajarannya menggunakan berbagai sumber belajar melalui teknologi komunikasi, informasi dan media lain.

Pendidikan di Indonesia kini mengalami cobaan setelah menyebarnya virus Covid-19 yang bersasal dari cina dan menyebar keseluruh negara di dunia termasuk di Indonesia. Masrul (2020: 55) menyatakan bahwa Corona Virus Desease 2019 atau yang biasa disingkat Covid-19 adalah sejenis penyakit yang disebabkan oleh SARS-CoV-2 dan pertama kali ditemukan di kota wuhan, tiongkok di bulan desember akhir tahun 2019 kemudian mulai menyebar keberbagai negara, dan tidak kecuali Indonesia. WHO sendiri menerapkan Covid-19 sebagai 
wabah pandemic pada tanggal 11 maret 2020 (WHO,2020). Kecepatan penyebaran wabah Covid-19 ini menjadikan banyaknya korban diberbagai negara. Di Indonesia sendiri jumlah korban Covid-19 semakin bertambah, pertanggal 19 april 2020 terkonfirmasi 6.248 kasus positif dengan 535 kasus meninggal dan 632 kasus sembuh (BNPB 2020).

Permasalahan virus Covid-19 ternyata memengaruhi dunia pendidikan di Indonesia, pembelajaran yang biasanya dilakukan di sekolah kini harus dilaksanakan dirumah masing-masing baik siswa maupun guru, hal tersebut dilakukan untuk menghindari penyebaran virus Covid-19. Sudarsana (2020: 79) menyatakan bahwa bidang pendidikan merupakan salah satu yang meraskan dampak virus Covid-19 . kehiatan belajar mengajar di dalam kelas yang selama ini dilaksanakan, mengalami perubahan seiring dengan adanya kebijakan pemerintah untuk bekerja, belajar dan beribadah dirumah. Artinya dengan belajar dirumah menuntut para pendidik untuk memastikan kegiatan belajar mengajar tetap berjalan, meskipun peserta didik belajar dirumah masing masing.

SD 2 Tenggeles Kecamatan Mejobo merupakan salah satu SD di Kabupaten Kudus yang melaksanakan proses pembelajaran daring dirumah seperti halnya sekolah yang lain. Dalam proses pembelajaran daring yang tiba-tiba dilaksanakan di Indonesia membuat sekolah, guru, siswa dan orang tua tidak siap melaksanakannya. Tentu banyak kendala dan permasalahan yang dialami oleh guru, siswa dan orang tua.

Untuk mencari kendala dan permasalahan tersebut Peneliti melakukan observasi dan wawancara tentang pembelajaran daring selama pandemi Covid -19 di SD 2 Tenggeles dengan subjek penelitian adalah guru, siswa dan orang tua siswa. Observasi menunjukan hasil dimana keterbatasan ruang dan waktu guru dalam proses mengajar, harus membuat rencana baru dalam proses mengajar, bagi guru yang memiliki anak menjadi kerepotan harus mengajar anak dan siswa. Tidak semua siswa langsung bisa menggunakan IT, jaringan internet kurang stabil, dan ada pula siswa yang tidak memiliki gatget atau laptop, keterbatasan ekonomi dan kurangnya interaksi langsung dengan guru. Tidak semua orang tua bisa membagi waktu antaar pekerjaan dan mendampingi anak dirumah, orang tua dituntut untuk mengeluarkan biaya teknologi bagi anak dan melek ilmu penegtahuan untuk mendamoingi anak dalam belajar.

$$
\text { Peneliti juga melakukan }
$$

wawancara pada tanggal 22 Sebtember 2020 dengan guru kelas VI SD 2 Tenggeles menunjukan bahwa pada mas pandemi Covid-19 mempengaruhi proses pembelajaran guru dan siswa di sekolah karena tidak bisa bertatap muka secara langsung dengan siswa dan pembelajaran yang seharusnya dilakukan disekolah menjadi terganggu karena harus berpindah kerumah sehingga membuat proses pembelajaran tidak efektif. Antusias murid terhadap tugas dan pembelajaran pun kurang. Peneliti juga merangkum wawancara dengan orang tua. Dengan adanya pandemi virus Covid-19 mempengaruhi proses pembelajaran anak seperti contoh yang dialami pada anak kelas 1 yang dulunya sebelum ada pandemi sudah bisa membaca kini banyak yang lupa. Perbandingan hasil belajar pun lebih baik ketika masih disekolah. Orang tua tidak bisa setiap waktu bisa mendampingi anaknya dalam belajar karena kesibukan pekerjaan dan kegiatan yang lain, pengeluaran biaya keuangan 
orang tua menjadi melonjak setelah adanya pandemi Covid-19.

Selain dengan guru dan orang tua siswa, peneliti juga merangkum wawancara dengan siswa mulai dari kelas 1 hingga kelas 6. Dimasa pandemi Covid19 mempengaruhi pembelajaran siswa disekolah akibat yang dirasakan siswa pun berragam mulai pembelajaran menjadi lebih sulit, tidal bisa belajar disekolah, tidak bisa bertemu dangan teman teman, pemahaman materi menjadi berkurang, dan siswa lebih merasa senang ketika belajar disekolah. Dalam pelaksanaan pembelajaran daring siswa menggunakan grub via aplikasi WhatsApp. Beberapa siswa merasa mengeluh karena tugas yang diberikan guru dirasa sulit, namun ada beberapa yang merasa tugas yang diberikan guru dirasa sedang atau mudah. Dari hasil observasi dan wawancara yang peneliti lakukan di SD 2 Tenggeles kepada guru, siswa dan orang tua dapat disimpulkan bahwa ternyata banyak kendala dan kekurangan yang dialami oleh guru, siswa dan orang tua dalam proses pembelajaran daring di SD 2 Tenggeles.

Penelitian tentang pembelajaran daring di sekolah dasar juga pernah dilakuakan oleh Purwanto (2020) dengan judul Studi Eksploratif dampak pandemi Covid-19 terhadap pembelajaran online di sekolah dasar. Hasil penelitian tersebut menunjukan bahwa terdapat beberapa kendala yang dialami oleh murid, guru dan orang tua dalam kegiatan belajar mengajar online yaitu penguasaan teknologi masih kurang, penambahan biaya kuota internet, adanya pekerjaan tambahan bagi orang tua dalam mendampingi anak belajar, komunikasi dan sosisalisasi antar siswa, guru dan orang tua menjadi berkurang dan jam kerja menjadi tidak terbatas bagi guru karena harus berkomunikasi dan berkoordinasi denga orang tua, guru lain dan kepala sekolah. Berdasarkan penelitian yang dilakukan oleh Purwanto (2020) dapat disimpulkan bahwa ternyata banyak kendala atau kekurangan yang dialami oleh guru, siswa dan orang tua.

Berdasarkan latar belakang permasalahan tersebut peneliti ingin meneliti lebih alam terkait permasalahan pembelajaran daring di SD 2 Tenggeles. Selain itu peneliti ingin menganalisa terkait dengan solusi untuk mengetahui kendala pembelajaran daring di SD 2 Tenggeles. Tujuan dalam penelitian ini adalah untuk mendeskripsikan kendala pembelajaran daring yang dialami oleh siswa, mendeskripsikan kendala pembelajaran daring yang dialami oleh guru dan memberikan solusi dari kendala tersebut.

Berdasarkan latar belakang tersebut peneliti membuat judul "Analisis pembelajaran daring di SD 2 Tenggeles Mejobo Kudus pada masa pandemi Covid19". Alasan peneliti melakukan penelitian terkait pembelajaran daring adalah untuk memberikan kontribusi ilmu pengetahuan terkait pandemi covid-19 yang terjadi di Indonesia dimana berdampak pada pembelajaran sekolah yang di alihkan untuk dilakukan dirumah sebagai bentuk penanggulangan penyebaran virus covid19.

\section{METODE}

Metode penelitian yang digunakan dalam penelitian ini adalah penelitian kualitatif deskriptif. Subjek penelitian yaitu satu siswa yang di ambil dari kelas I sampai kelas VI. Sumber data penelitian yaitu siswa, guru, dan orang tua siswa. Teknik analisis data yang peneliti gunakan adalah analisis model interaktif (interactive model analysis) dari Miles dan Huberman dalam Prihati (2018: 41). Dalam teknik analisis model interaktif ini 
setelah dikumpulkan data maka kegiatan analisis dilakukan dengan mengikuti pola interaksi anata reduksi data, display data, dan penarikan kesimpulan atau verivikasi, yang digambarkan sebagai berikut:

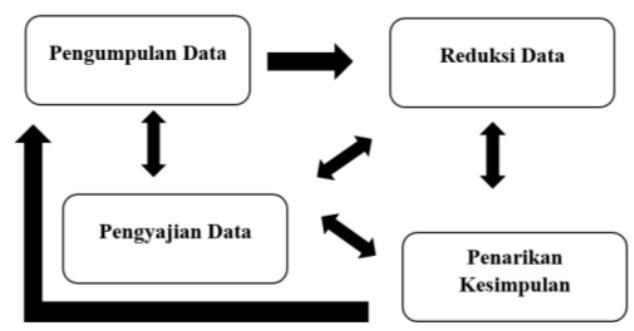

Gambar 1. Analisis model interaktif

Sumber: Prihati (2018: 41)

Teknik pengumpulan data meliputi teknik wawancara, observasi dan dokumentasi.

\section{HASIL DAN PEMBAHASAN}

a. Kendala Pembelajaran Daring Siswa

Peneliti melaukan wawancara kepada beberpa siswa SD 2 Tenggeles baik secara langsung dan melalui video call.

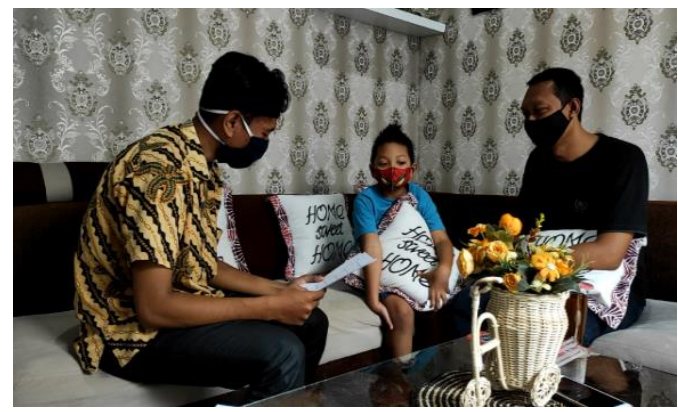

Gambar 1. Wawancara dengan siswa I

Wawancara yang pertama adalah dengan MH Dari hasil wawacara peneliti menemukan beberapa kendala yang dialamai $\mathrm{MH}$ dalam melakukan pembelajaran daring dirumah adalah merasa pembelajaran menjadi sulit karena hanya diberikan soal-soal saja selain itu soal yang diberikan panjang-panjang oleh guru, seperti halnya siswa yang lain $\mathrm{MH}$ merasa lebih senang ketika belajar disekolah dengan teman dan guru, dalam pembelajaran daring dirumah pun $\mathrm{MH}$ tidak pernah melakukan belajar kelompok dengan teman-temannya. Dalam data yang ditemukan informan mengemukakan bahwa :

"Sekolah, karena disekolah banyak teman yang bisa di ajak bermain."

"Pembelajaran menjadi sulit, karena hanya dikasih soal-soal."

"Sulit karena ibu guru memberikan soal yang panjang-panjang."

Hal tersebut menunjukan bahwa dalam melakukan pembelajaran dirumah siswa juga jarang bertemu dengan temantemannya, hubungan antar teman mempengaruhi semangat siswa dalam melakukan pembelajaran. Selain hubungan atara teman kendala yang dialami $\mathrm{MH}$ selanjunya adalah pembelajaran menjadi sulit karena hanya dikasih soal-soal, selain itu soal yang diberkan juga panjang-panjang. $\mathrm{MH}$ merasa pembelajaran daring yang dilakukan dirumah hanya diberikan soal oleh guru hal tersebut menunjukan bahwa antara soal-saol dan pembelajaran atau materi yang diberikan oleh guru ternyata menurut MH lebih banyak diberikan soalsoal saja. Namun tidak dipungkiri dalam pembelajara daring guru tidak bisa maksimal dalam memberikan materi pembelajaran seperti ketika di lakukan di Sekolah karena keterbatasan waktu dan kuota internet yang terbatas pula.

Wawancara yang kedua adalah dengan AR siswa kelas 2 SD 2 Tenggeles yang peneliti lakukan melalui Video call. Dari wawancara yang peneliti lakukan dengan AR peneliti menemukan ada 
beberapa kendala yang di alami AR dalam proses pembelajaran daring salah satu diantaranya adalah AR merasa lebih senang ketika belajar disekolah karena lebih faham materi yang di terangkan oleh guru yang kedua adalah tidak pernah datang kesekolah. Dalam data yang ditemukan informan mengemukakan bahwa:

"Lebih senang ketika disekolahan karena lebih faham materi yang di terangkan oleh guru."

Hal tersebut menunjukan bahwa ternya pembelajaran yang dilakukan disekolah dengan yang dilakukan daring siswa lebih faham ketika disekolah karena ketika disekolah pembelajaran diterangkan secara langsung oleh guru, namun kendala yang kendala yang dialamai AR tersebut dapat di antisipasi dengan mengikuti les atau bimbil sehingga siswa akan tetap memahami pelajaran karena mengikuti les atau bimbel.

Wawancara selanjutnya adalah dengan ALN yang peneliti lakukan melalui Video call atau panggilan video. Dalam data yang ditemukan informan mengemukakan bahwa:

" Materi pembelajaran sulit difahami dan hanya di kasih soal-soal saja."

"Sulit karena belum faham dengan materi yang diajarkan."

Hal tersebut menunjukan bahwa pademi Covid-19 membawa dampak bagi bagi pembelajaran disekolah yaitu siswa merasa materi pembelajaran menjadi lebih sulit untuk difahami. Tingkat pemahaman siswa dalam materi pembelajaran menjadi rendah dibandingkan dengan ketika disekolah hal tersebut menunjukan bahwa peran guru sangat besar dalam tingkat pemahaman materi oleh siswa. Dalam situasi pandemi seperti ini yang mengharuskan kegiatan pembelajaran harus dilakukan disekolah membuat jarak antara siswa dan guru tidak lagi dekat seperti dulu pembelajaran yang dilakukan secara daring ternyata mebawa dampak yang signifikan dalam tingkat pemahaman materi siswa. Disisi lain siswa berpandangan dalam pembelajaran daring hanya diberikan soal-soal saja.

Wawancara selanjutnya adalah dengan SGK yang peneliti lakukan melalui video call atau panggilan video dari wawancara tersebut peneliti menemukan kendala yang dialami SGK dalam pembelajaran daring yaitu SGK merasa ketika pembelajaran dirumah tidak bisa bertemu dengan teman teman. Seperti yang dikemukakan ketika peneliti bertanya apa akibat yang ditimbulkan dengan adanya pandemi Covid-10 bagi pembelajaran disekolah:

\section{"Tidak bisa belajar dengan teman-} teman."

Interaksi antar sisama teman atau siswa harus tetap berjalan agar dalam pembelajaran daring yang dilakukan dirumah tidak membuat siswa merasa stress atau jenuh. Disisilain dengan bertemu dengan siswa yang lain siswa dapat melakukan belajar kelompok agar siswa dapat saling berinteraksi dan berdiskusi tentang materi peelajaran.

Wawancara selanjutnya adalah dengan LPM yang peneliti lakukan melalui video call atau panggilan video dari hasil wawancara tersebut peneliti menemukan beberapa kendala yang dialamu oleh LPM dalam pembelajaran daring salah satu diantaranya adalah siswa merasa pembelajaran menjadi sulit, dengan pemahaman materi yang kurang yang kedua adalah LPM merasa sedih ketika pembelajaran dirumah karena tidak bisa belajar dengan teman-teman yang bisa diajak bermain lalu yang ketiga adalah LPM merasa sedih ketika pembelajaran dirumah karena tidak bisa 
belajar dengan teman-teman yang bisa diajak bermain Dalam data yang ditemukan informan mengemukakan bahwa :

"Ada senangnya dan ada sendihnya tetapi banyak sedihnya karena tidak bisa belajar dengan tema-teman dan bosen belajar sendiri."

"Disekolah karena banyak teman yang bisa diajak main."

"Sulit karena pak guru hanya memberikan soal saja dan kita harus memahami materi sendiri melalui youtube."

Seperti yang terjadi pada siswa sebelumnya permasalahan yang dialami oleh LPM adalah merasa sedih karena tidak bisa belajar dengan teman-temannya hal tersebut menujukan bahwa hubungan pertemanan mempengaruhi semangat belajar siswa. LPM pun membandingkan tingkat kebahagiaan dalam belajar lebih senang ketika disekolah disbanding dirumah. Kendala selanjutnya LPM merasa tugas yang diberikan oleh gurunya dirasa sulit karena disisilain yang hanya memberikan soal saja siswa harus mampu memahami materi pelajaran yang ada di internet yaitu melalui aplikasi youtube dan google.

Dari sini peneliti menganalisa bahwa perbandingan anatar melihat atau menyimak materi pelajaran yang dilakukan secara langsung dengan tidak langsung lebih dipahami oleh siswa jika dilakukan secara langsung atau secara tatap muka. Dengan interaski secara langsung siswa akan lebih faham dan mengerti tentang materi yang diterangkan.

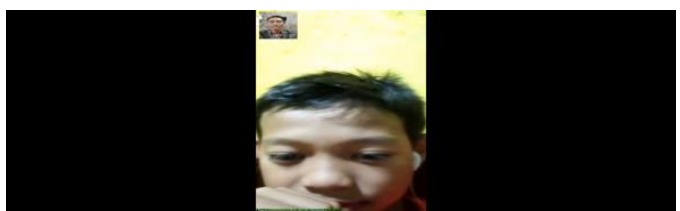

Gambar 2. Wawancara dengan Siswa II
Wawancara dengan siswa yang terakrih adalah dengan MI yang peneliti lakukan secara langsung dengan tetap menggunakan protocol kesehatan. Dari hasil wawacara dapat peneliti menemukan beberapa kendala yang dialamai MI yaitu merasa sedih kerena tidak be-isa bertemu dengan teman dan tidak pernah belajar bersama dengan temannya. Dalam data yang ditemukan informan mengemukakan bahwa:

"Tidak bisa belajar disekolah"

"Sedih karena tidak bisa bertemu dengan teman-teman."

"Tidak ada karena belajar sendirisendiri dirumahnya."

Dari kendala yang dialami oleh MI kurang lebih sama dengan siswa yang lain yaitu merasa sedih karena tidak bisa bertemu dengan teman sejawatnya disisiain tidak bisa belajar bersama dengan temannya.

Selain wawancara peneliti juga melakukan observasi. Berdasarkan hasil observasi peneliti menemukan beberapa kendala yang dialami oleh siswa yaitu ada siswa yang tiak memiliki gadget atau laptop, kurangnya interaksi langsung dengan guru dan siswa mudah bosan atau jenuh. Hal tersebut menunjukan kendalakendala yang dialami oleh siswa.

Selain wawancara peneliti juga melakukan observasi. Berdasarkan hasil observasi peneliti menemukan beberapa kendala yang dialami oleh siswa yaitu ada siswa yang tiak memiliki gadget atau laptop, kurangnya interaksi langsung dengan guru dan siswa mudah bosan atau jenuh. Hal tersebut menunjukan kendalakendala yang dialami oleh siswa.

Berdasarkan obervasi dan wawancara peneliti menemukan kesamaan kendala yang ditemukan oleh Purwanto (2020) .dari penelitian tersebut menunjukan bahwa hasil penelitian 
terdapat beberapa kendala yang dialami oleh siswa yaitu merasa dipakasa belajar dengan jarak jauh tanpa sarana dan prasarana memadai di rumah. Fasilitas ini sangat penting untuk kelancaran proses belajar mengajar, kendala selanjutnya yang dialami adalah sekolah diliburkan terlalu lama membuat siswa jenuh, siswa mulai jenuh di rumah dan ingin segera kembali ke sekolah untuk bermain dengan teman-temannya, siswa terbiasa berada di sekolah untuk berinteraksi dengan temantemannya.

\section{b. Kendala Pembelajaran Daring Guru}

Wawancara yang pertama adalah dengan Bapak KH guru kelas VI SD 2 Tenggeles. Yang peneliti lakukan secara langsung. Berdasarkan hasil wawancara yang peneliti lakukan kepada guru SD 2 Tenggeles adalah pada masa pandemi covid-19 mempengaruhi proses pembelajaran guru kerena tidak bisa bertemu dan mengajar secara langsung dengan siswa, jadi terjadi kesulitan dalam memberikan materi pelajaran kepada siswa, pembelajaran disekolah menjadi terganggu dan menjadi tidak efektif dan kurang maksimal, dimana yang sebelunya dalam satu hari bisa selesai satu pembelajaran kini menjadi terpangkas. Dalam data yang ditemukan informan mengemukakan bahwa:

"Jelas mempengaruhi, karena tidak bisa bertemu langsung dengan siswa, jadi terjadi kesulitan dalam memberikan materi pelajaran yang diamanantkan kurikulum kepada kita dalam pembelajaran pun mau tidak mau harus kita pangkas atau kita singkat."

"Terus terang sangat terganggu dan menjadi tidak efektif, yang sebenarnya satu hari bisa selesai satu
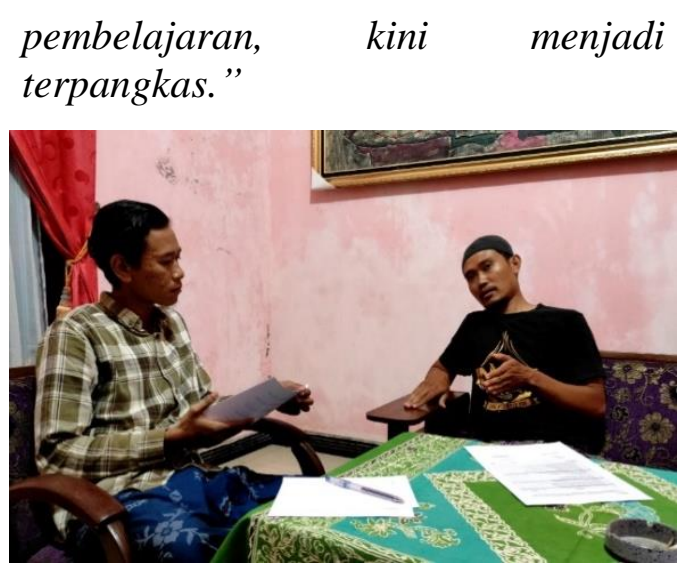

Gambar 3. Wawancara dengan Guru I

Dari pernyataan tersebut menunjukan bahwa dalam pandemic Covid-19 mempengaruhi proses pembelajaran Guru karena tidak bisa bertemu kembali dengan siswa pembelajaran pun menjadi kurang efektif yang dimana dalam satu hari guru bisa menyelesiakan satu pembelajaran saat masih disekolah namun kini harus terpangkas karena keterbatasan waktu atau kuota internet baik bagi guru sendiri atau bagi siswa. Hal tersebut menjadikan kendala dalam penyampaian materi kepada siswa. Bapak $\mathrm{KH}$ juga menambahkan bahwa terdapat permasalahan lain yang dialami oleh siswa seperti yang dikemukakan:

"Kalau pada awal pembelajaran daring saya memakai aplikasi zoom, namun dalam berjalannya waktu, yang mengikuti proses pembeajaran sedikit, setelah saya selidiki ternyata ada anak yang tidak mempunyai HP ada juga anak yang dalam satu keluarga bergantian $h p$ dengan saudaranya."

"Ketika saya memberi tugas, seperti contoh pagi hari saya memeberikann tugas dengan memberikan link di grub yaitu dari youtube dengan harapan di tonton dan dipelajari, 
setelah itu saya suruh untuk mengisi evaluasi pembelajaran di google form, namun dari total 30 an siswa hanya 18 siswa yang megumpulkan tugas."

Berdasarkan pernyataan tersebut menunjukan bahwa hubungan komunikasi antara guru dan siswa ternyata kurang berjalan dengan lancar dimana ada siswa yang masih belum mempunyai hp sebagai alat komunikasi antara guru dan siswa dan ada pula siswa yang harus bergantian dengan saudaranya dalam menggunakan hp.

Permasalahan tersebut tidak dapat dipungkiri dimana latar belakang keluarga setiap siswa memang berbeda beda. Antusiasme siswa dalam mengikuti pembelajaran daring pun dirasa kurang oleh guru hal tersebut dapat dilihat saat guru memberikan tugas hanya beberapa siswa saja yang mengumpulkan.

Wawancara dengan guru selanjutnya adalah dengan Ibu AS Guru kelas IV yang peneliti lakukan secara langsung di SD 2 Tenggeles.

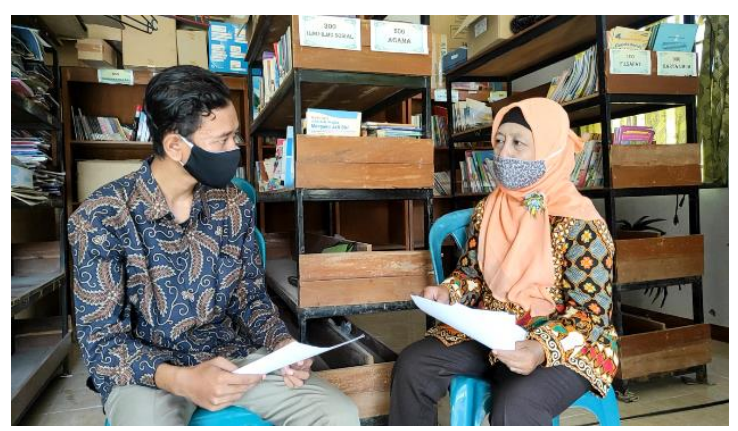

Gambar 4. Wawancara dengan Guru II

Dari hasil wawancara dapat peneliti simpulkan bahwa dalam pembelajaran di masa pandemi Covid-19 guru merasa pembelajaran menjadi kurang maksimal karena tidak dilakukan secara tatap muka atau secara langsung dengan siswa. Dalam data yang ditemukan informan mengemukakan bahwa:

"Pembelajaran menjadi kurang maksimal, karena tidak bertatap muka secara langsung dengan siswa."

Sebagaimana yang diharapkan oleh siswa dimana pembelajaran diharapkan secara tatap muka Ibu AS juga mengharapkan demikian, dimana guru mengeluhkan tentang pembelajaran yang menjadi kurang maksimal kerena tidak dilakukan secara langsung. Kendala selanjutnya yang dialami oleh Ibu AS adalah tentang atusias murid dalam mengikuti pembelajaran, sebagaimana yang beliau kemukakan:

"Sebagian ada yang mau mengikuti dan sebagian ada pula yang tidak antusia atau mengabaikan."

Keluhan yang dialami oleh Bapak $\mathrm{KH}$ ternyata kurang lebih sama dengan apa yang dialami oleh Ibu AS dimana murid kurang antusias dalam mengikuti proses pembelajaran daring bahkan ada juga yang mengacuhkan.

Selain itu Ibu guru juga menilai bahwa dalam peran orang tua kepada siswa dalam proses pembelajaran daring adalah sebagian orang tua mau membantu siswa dalam belajar namun ada juga beberapa siswa yang masih kurang mendapat perhatian dari orang tuanya. Selanjutnya dalah pembelajaran daring kurang maksimal karena yang tidak dilakuakn secara tatap muka membuat hasil evaluasi pembelajaran menjadi kurang maksimal. Kendala yang dialami Ibu AS selanjutnya adalah tentang pengaruh orang tua terhadap hasil belajar siswa dalam proses pembelajaran daring sebagaimana yang beliau kemukakan:

"Sebagian besar ada yang membantu siswa, dan ada juga siswa yang kurang perhatian." 
"Pembelajaran menjadi kurang maksimal, karena tidak dilakukan secara tatap muka sehingga evaluasi tidak sesuai kemampuan siswa sendiri."

Pengaruh orang tua kepad siswa dalam pembelajaran daring ternyata berpengaruh signifikan dlaam perkembangan belajar anak simana anak yang mendapatkan perhatian spesial akan dapat mengikuti pelajaran dengan baik, begitupun sebaliknya anak yang kurang medapat perhatian akan kurang dalam mengikuti pelajaran. Disisilain peran orang tua yang terlalu over tanpa batasan dapat mempengaruhi hasil belajar siswa juga sebagai mana pernyataan di atas yaitu hasil evaluasi pembelajaran siswa menjadi tidak sesuai dengan kemampuannya sendiri hal itu sejalan dengan apa yang di temukan oleh Bapak KH dimana anak yang mendapatkan perhatian spesial akan mendapatkan nilai yang bagus dan begitu pun sebaliknya.

Selain wawancara kepad guru peneliti juga melakukan obervasi dalam menggali informasi untuk emnemukan kendala pembelajaran daring yang di rasakan oleh guru. Dari hasil observasi peneliti menemukan beberapa kendala yang di rasakan oleh guru yaitu keterbatasan ruang dan waktu dalam proses mengajar, harus membuat rencana baru dalam mengajar dan guru menjadi kerepotan bagi yang mempunyai anak harus mengajar anak dan siswanya.

Penelitian ini sejalan dengan penelitian yang dilaukan oleh Setyorini (2020) dari penelitian tersebut menunjukan bahwa hasil penelitian terdapat beberapa kendala yang dialami oleh guru yaitu guru mengidentifikasi lebih banyak tantangan dan kendala, termasuk beberapa pembatasan dalam pilihan metode pengajaran yang biasanya berlaku di kelas tatap muka, cakupan materi kurikulum lebih sedikit. Dan waktu layar yang lebih lama sebagai hasil dari pembuatan konten-e dan memberikan umpan balik kepada pekerjaan siswa, komunikasi yang lebih intens dan memakan waktu dengan orang tua. Dalam berkomunikasi dengan siswa guru juga sama-sama menggunakan apliasi WhatsApp Group untuk berdiskusi dan dan berbagi dokumen dengan siswa. Selanjutnya penelitian sejalan dengan penelitian yang dilakukan oleh Purwanto (2020) dari penelitian tersebut menunjukan bahwa guru belum ada budaya belajar jarak jauh karena selama ini system belajar dilaksanakan adalah melalui tatap muka, para guru pun terbiasa belajar disekolah dengan murid-murid.

\section{c. Kendala Pembelajaran Daring Orang Tua Siswa}

Sebagai penguat peneliti melakuakan wawancara dengan orang tua siswa yaitu Ibu SGK untuk mengetahui kendala yang dialami siswa dan orang tua. peneliti melakukan wawancara melalui video call atau panggilan video

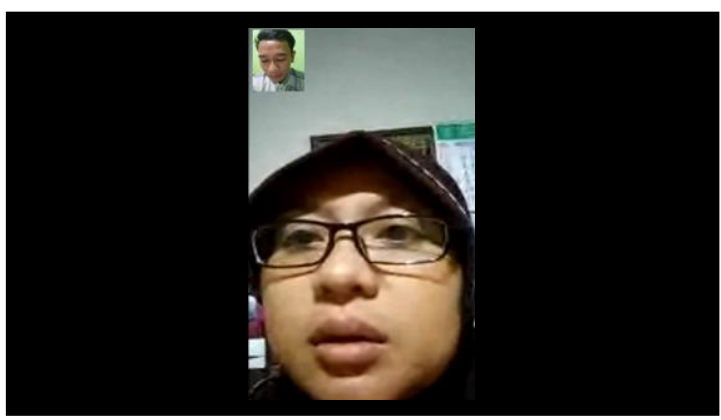

Gambar 5. Wawancara dengan orang tua siswa

Hasil wawancara dengan orang tua siswa yaitu dengan adanya virus Covid-19 mempengaruhi proses pembelajaran anak disekolah karena kalau belajar dirumah orang tua menjadi siring merasa keasal dan lelah karena orang tua baru bisa 
menemani anak belajar setelah pulang kerja, orang tua juga menilai bahwa pembelajaran daring yang dilakukan anak dirumah adalah kurang efektif dan lebih baik belajar di sekolah. Dalam data yang ditemukan informan mengemukakan bahwa:

"Lebih baik belajar disekolah, dan kalau belajar dirumah saja menjadi sering merasa kesal dan lelah."

"Iya, setelah saya pulang kerja atau ketika habis mahrib."

"Kurang efektif, dan lebih baik belajar disekolah."

Berdasarkan pernyataan yang dikemukaan Ibu NSH bahwa orang tua merasa kesulitan dalam mendampingi dan mengajari anak alam melakukan pembelajaran daring karena baru bisa mendampingi anak setelah pulang kerja, hal tersebut tentu membuat orang tua merasa lelah, namun tidak dipungkiri bahwa kewajiban orang tua harus berperan menggantikan guru dalam mengasuh, mengawasi dan mengajari anak alam proses pembelajaran daring selain itu Ibu NSH juga menilai bahwa pembelajaran daring kuarang efektif dan lebih baik dilakukan disekolah. Kendala selanjutnya adalah mengenai biaya kebutuhan anak untuk pembelajaran daring sebagaimana yang beliau kemukakan:

"Menjadi melonjak atau mengalami kenaikan.'

Perbandingan biaya keuangan anak anatara sebelum dan sesudah pandemi mengalami kenaikan. Kenaikan biaya anak tersebut tidak lain untuk kebutuhan biaya kuota internet anak disisilain Ibu NSH juga memiliki 2 anak yang masih sekolah SD. Sebagai penguat yang kedua peneliti melakuakan wawancara dengan Bapak IA orang tua dari siswa kelas 1.

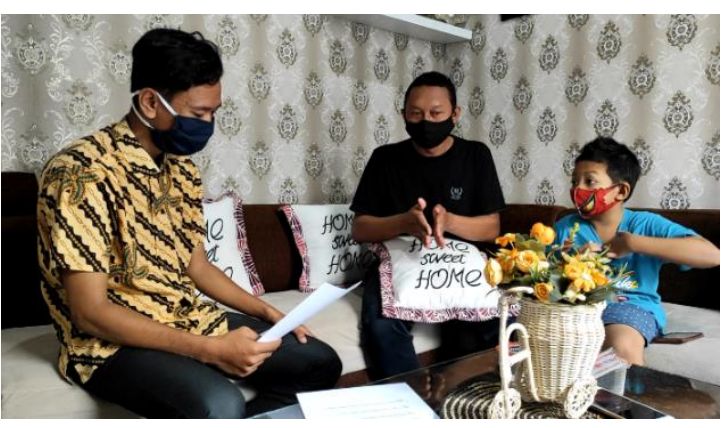

Gambar 6. Wawancara dengan orang tua siswa

Hasil wawancara dengan orang tua siswa yaitu dengan adanya virus Covid-19 mempengaruhi proses pembelajaran anak disekolah karena orang tua merasa yang sekolah bukan lagi anaknya melainkan tergantikan oleh orang tua, selanjutnya orang tua menilai anak dahulu sesudah bisa membaca dan menguasai pelajaran namun setelah adanya pandemi sudah banyak yang lupa, Dalam data yang ditemukan informan mengemukakan bahwa:

"Yang pasti sangat mempengaruhi karena yang sekolah bukan lagi anak, melainkan tergantikan orang tua."

"Banyak pengaruhnya, salah satunya contoh anak saya sendiri yang dulunya sudah bisa membaca namun setelah pembelajaran berlaih kerumah kini banyak yang lupa."

Berdasarkan pernytaan yang dikemukakan oleh Bapak IA bahwa setelah adanaya pembelajaran daring dirumah orang tua merasa yang sekolah bukan lagi siswa namun tergantikan oleh orang tua dimana orang tua. Disini orang tua berperan untuk menemani anak dalam belajar dan membantu mengerjakan tugas siswa tidak jadi secara tidak langsung orang tua menggantikan peran siswa dalam sekolah.

Kendala selanjutnya adalah tentang perkembangan anak dalam pembelajaran 
daring orang tua menilai perkembangan anak menjadi menurun seperti yang dikemukakan bahwa anak yang dulunya sudah bisa membaca kini sudah banyak yang lupa menginat anak dari Bapak IA baru kelas 1 yaitu baru belajar membaca. Dengan pembelajaran dirumah pengawasan guru dalam belajar memang berkurang disinilah sebagai orang tua seharusnya memberikan stimulan dan arahan serta latihan kepada anak untuk tetap belajar membaca dan belajar mata pelajaran yang lain.

Kendala selanjutnya adalah tentang pengeluaran biaya bulanan orang tua untuk anak sebagaimana yang beliau kemukakan:

"Pengeluaran tentu menjadi lebih banyak ketika adanya pandemi, karena anak membutuhkan kuota internet dan anak hanya mau belajar ketika sudah dituruti kemauannya.'

Berdasarkan pernyataan tersebut dapat disimpulkan bahwa setelah adanya pembelajaran daring dirumah pengeluaran biaya menjadi naik mengingat dalam pembelajaran daring membutuhkan kuota internet sebagai penunjang alat komunikasi antara guru dan siswa.

\section{d. Solusi Kendala Pembelajaran Daring}

Setelah melakukan observasi kepada Siswa, Guru dan Orang tua di SD 2 Tenggeles ternyata banyak sekali kendala yang dialami oleh Siswa, Guru dan Orang tua. Dari kendala tersebut perlunya utnuk di evaluasi agar nantinya pembelajaran daring dapat berjalan dengan lancar, sesuai harapan mengingat bahwa pandemi Covid-19 belum juga mereda.

Berikut peneliti rangkumkan kendala pembelajaran daring yang telah peneliti temukan sebelumnya kedalam bentu tabel agar lebih mudah dalam membacanya.

Tabel 1. Kesamaan Kendala

Pembelajaran daring

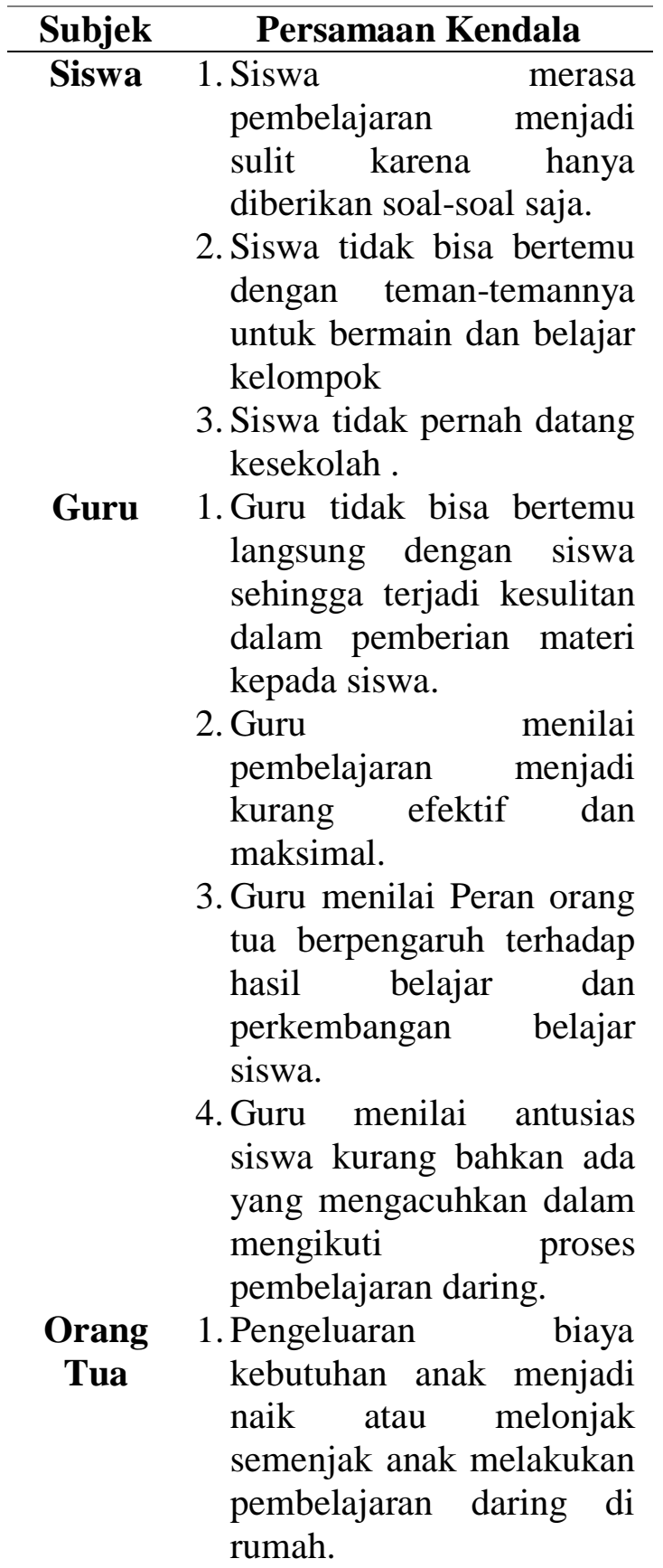


Tabel 2. Perbedaan Kendala

\begin{tabular}{cl} 
& Pembelajaran Daring \\
\hline Subjek & \multicolumn{2}{c}{ Perbedaan Kendala } \\
\hline Siswa & $\begin{array}{l}\text { 1. Siswa merasa jenuh } \\
\text { melakukan pembelajaran }\end{array}$ \\
& daring dirumah. \\
& 2. Siswa merasa senang \\
& melakukan pembelajaran \\
daring disekolah karena & lebih faham materi yang \\
diterangkan oleh guru. \\
3. Siswa merasa tugas yang \\
diberikan oleh guru di rasa \\
sulit karena belum \\
memahami materi yang \\
diajarkan.
\end{tabular}
Guru 1. Hubungan komunikasi antara guru dan siswa kurang maksimal

Orang 1. Orang tua merasa kesal

Tua dan lelah karena harus menemani dan membantu anak bekajar.

2. Orang tua menilaip pembelajaran daring kurang efektif

3. Orang tua menilai yang sekolah tidak lagi anak melainkan tergantikan oleh orang tua.

4. Kemampuan dan pemahaman anak terhadap materi pelajaran di sekolah menurun.

Peneliti menyimpulkan kendalan yang dialami oleh siswa adalah tentang keluhan siswa yang tidak pernah datang kesekolah disisilain dalam proses pembelajaran daring siswa tidak pernah bertemu dengan teman temannya hal tersebut mengakibatkan siswa merasa jenuh dalam belajar dirumah. Harapan siswa adalah setidaknya belajar disekolah agar bisa mendengarkan pembelajaran dari guru karena siswa mengaku lebih faham tentang apa yang diterangkan guru disbanding dengan melihat atau menyimak pembelajaran yang ada di internet seperti yang salah satu siswa kemukakan:

"Sulit karena pak guru hanya memberikan soal saja dan kita harus memahami materi sendiri melalui youtube."

"Materi pembelajaran sulit difahami dan hanya di kasih soal-soal saja."

"Ada senangnya dan ada sendihnya tetapi banyak sedihnya karena tidak bisa belajar dengan tema-teman dan bosen belajar sendiri"

"Disekolah karena banyak teman yang bisa diajak main."

Berdasarkan pernyataan siswa tersebut menunjukan bahwa pada umumnya permasalahan yang dialami siswa adalah kejenuhan karena selalu belajar dirumah, kejenuhan itu di perparah karena tidak bisa bertemu dengan temannya disisilain pemahaman materi siswa kurang karena peran guru tergantikan oleh materi materi yang ada di internet atau video youtube. Nuris (2019: 21) Menyatakan bahwa untuk mendukung hasil positif dalam mencapai hasil pembalajaran yang baik maka diperlukan dukungan faktor lain yaitu motivasi. Berdasarkna pendapat diatas dapat disimpulkan bahwa untuk mendukung hasil positif dalam mencapai hasil pembelajaran yang baik maka diperlukan faktor lain dimana dalam kendala yang dialami siswa adalah tidak pernah belajar disekolah disisilain siswa lebih senang ketika melakukan pembelajaran disekolah karena banyak teman.

Maka dapat disimpulkan bahwa solusi kendala yang dialami siswa adalah siswa dapat melakukan belajar kelompok bersama teman diharapkan dalam belajar 
kelompok bersama teman dirumah akan dapat saling berdiskusi dalam memahami materi pelajaran disisilain siswa akan lebih termotivasi dan semangat dalam melakukan pembelajaran daring dirumah.

Selanjutnya adalah kendala yang dialami oleh guru menyimpulkan bahwa kendala yang dialami oleh guru adalah pembelajaran menjadi kurang maksimal karena keterbatasan komunikasi dengan siswa yang hanya dilakukan melalui daring saja sebagaimana yang guru kemukakan sebagai berikut:

"Pembelajaran menjadi kurang maksimal, karena tidak dilakukan secara tatap muka sehingga evaluasi tidak sesuai kemampuan siswa sendiri."

"Jelas mempengaruhi, karena tidak bisa bertemu langsung dengan siswa, jadi terjadi kesulitan dalam memberikan materi pelajaran yang diamanantkan kurikulum kepada kita dalam pembelajaran pun mau tidak mau harus kita pangkas atau kita singkat."

Dari kedua pendapat guru tersebut menunjukan bahwa guru merasa pembelajaran kurang maksimal dan kurang efektif dimana saat disekolah guru bisa menyelesaikan 1 pembelajaran dalam satu hari kini harus terpangkas, disisilain guru menilai hasil evaluasi belajar siswa menjadi kurang relevan dengan kemampuan siswa karena ada peran orang tua dalam pembelajaran dairumah. Sebagaimana yang dikemukakan:

"Pembelajaran menjadi kurang maksimal, karena tidak dilakukan secara tatap muka sehingga evaluasi tidak sesuai kemampuan siswa sendiri."

Hal tersebut menunjukan bahwa peran orang tua mempengaruhi hasil evaluasi belajar siswa dan harapan guru adalah pembelajaran yang dilakukan secara tatap muka agar guru dapat menilai perkembangan belajar siswa dalam mengikuti pembelajaran disisilain guru dapat melihat kemampuan siswa dalam mengerjakan soal-soal yang diberikan. Lalu solusi dari kenala yang di alami oleh guru adalah guru dapat menghimbau orang tua dalam menemani anak saat belajar untuk memberikan batasan dalam mengajari anak yaitu untuk membiarkan anak mengerjakan soal evaluasi agar dapat melihat kemampuan anak dalam menguasai materi pelajaran.

Yusuf (2018: 134) Menyatakan bahwa guru yang profesional diyakini mampu memotivasi siswa untuk mengoptimalkan potensinya dalam rangka pencapaian standar pendidikan yang diterapkan. Berdasarkan kutipan tersevut diharapkan bagi guru untuk dapat memotivasi semangat belajar siswa walaupaun dilakukan secara daring dirumah atau tidak bertatap muka secara langsung dengan guru sehingga siswa tetap semangat dalam belajar dirumah.

Dari kedua kendala yang dialami antara siswa dan guru tersebut peneliti melihat satu kesamaan antar siswa dan guru yaitu sama-sama ingin bertemu di sekolah agar terjadi interaksi dimana siswa mengharapkan pemaparan materi pelajaran yang disampaikan oleh guru dan guru ingin melihat secara langsung kemampuan siswa dalam menguasai materi pelajaran. Namun kedua harapan tersebut tidak pernah terwujud karena dari pembelajaran daring yang sudah berlangsung siswa mengaku tidak pernah datang kesekolah untuk melakukan pembelajaran.

Maka peneliti memberikan solusi dari permasalahan tersebut yaitu adalah melalui pembelajaran berbasis Blended 
Learning. Adi (2018: 7) menyatakan bahwa penegrtian pembelajaran berbasis blanded learning adalah pembelajaran yang mengkombinasi strategi penyampaian pembelajaran menggunakan kegiatan tatap muka, pembelajaran berbasis computer (offline), dan computer secara online (internet dan mobile learning). pembelajaran blanded dapat menggabungkan pembelajaran tatap muka (face to face) dengan pembelajaran berbasis computer. Dapat disimpulkan bawah pembelajaran berbasis Blended Learning adalah pembelajaran yang menggabungkan pembelajaran tatap muka dan pembelajaran berbasis computer atau dalam jaringan atau online.

Dengan pembelajaran berbasis Blended Learning diharapkan permaslahan yang pembelajan daring yang terjadi di SD 2 Tenggeles dapat terjawab. Harapannya adalah dalam pembelajaran daring setidaknya ada beberpa pertemuan yang dilakukan secara langsung atau tatap muka sehingga terjadi interaksi pembelajaran antara guru dan siswa sehingga siswa dapat mendengarkan pemaparan materi dari guru dan guru juga dapat melihat kemampuan siswa dalam menguasai pelajaran.

\section{KESIMPULAN}

Berdasarkan hasil penelitian yang dilakukan di SD 2 Tenggeles tentang pembelajaran daring selama pandemi Covid-19 dapat disimpulkan bahwa ada beberapa kendala yang dialami oleh siswa dan guru dalam pelaksanaan pembelajaran daring.

Salah satu kendala yang dialami siswa adalah kendala yang dialami oleh siswa yaitu siswa merasa jenuh karena selalu belajar dirumah, siswa tidak pernah bertemu untuk belajar dengan temannya dan siswa merasa kurang faham dalam memahami materi pelajaran kerena hanya menyimak dan membaca materi dari internet bukan dari guru. Solusi kendala yang dialami siswa adalah siswa dapat melakukan belajar kelompok bersama teman diharapkan dalam belajar kelompok bersama teman dirumah akan dapat saling berdiskusi dalam memahami materi pelajaran disisilain siswa akan lebih termotivasi dan semangat dalam melakukan pembelajaran daring dirumah.

Selain itu kendala yang dialami guru adalah guru merasa pembelajan kurang maksimal kerena guru tidak bisa menyampaikan meteri secara tatap muka dan guru tidak bisa milhat perkembangan siswa menguasai materi pelajaran. diharapkan bagi guru untuk dapat memotivasi semangat belajar siswa walaupaun dilakukan secara daring dirumah atau tidak bertatap muka secara langsung dengan guru sehingga siswa tetap semangat dalam belajar dirumah. . solusi selanjutnya dari kenala yang di alami oleh guru adalah guru dapat menghimbau orang tua dalam menemani anak saat belajar untuk memberikan batasan dalam mengajari anak yaitu untuk membiarkan anak mengerjakan soal evaluasi agar dapat melihat kemampuan anak dalam menguasai materi pelajaran.

Solusi dari kendala yang dialami oleh siswa adalah orang tua selain mengasuh dan menemani anak dalam belajar diharapkan juga menggantikan peran guru untk mengajari anak dalam memahami materi pelajaran yang sulit dan siswa diharapkan untuk bisa belajar kelompok dengan teman agar tidak jenuh dalam belajar dirumah. Lalu solusi dari kenala yang di alami oleh guru adalah guru dapat menghimbau orang tua untuk membiarkan anak mengerjakan soal evaluasi agar dapat melihat kemampuan anak dalam menguasai materi pelajaran. 
Berdasarkan kendala yanag dialami oleh siswa dan guru dapat di simpulkan bahwa terdapat satu kesamaan yaitu saling mengharapkan untuk bisa datang kesekolah guna melakukan pembelajaran secara tatap muka, maka solusi dari permasalah tersebut adalah dengan dilakukan kannya pembelajaran berbasis Blended Learning yaitu pembelajaran yang menggabungkan antara pembelajaran tatap mukan dan pembelajaran berbasis computer atau dalam jaringan.

\section{DAFTAR PUSTAKA}

Adi, S. (2018). Landasan Pengembangan Sekolah Olahraga. Malang: Wineka Media.

Khadir, A. (2012). Dasar- dasar Pendidikan. Jakarta: Kencana.

Masrul, dkk. (2020). Pandemi Covid-19: Persoalan dan Refleksi di Indonesia. Medan: Yayasan kita Menulis.

Nuris, M. D. (2019). Motivasi Belajar dan Kompetensi Pedagogik Serta Pengaruhnya Terhadap Hasil Pembelajaran pada Program Keahlian Akuntansi Lectura Jurnal Pendidikan. 10 (1): 19-32.

Prihati. (2018). Implementasi Kebijakan Promosi Pariwisata Dalam Pengembangan Potensi Wilayah Daerah. Surabaya: CV. Jakad Publishing.

Purwanto, A., dkk. (2020). Studi Eksploratif Dampak Pandemi Covid-19 Terhadap Proses Pembelajaran Online di Sekolah Dasar. Jurnal of Education,
Psycology and Counseling. 2 (1): 2716-4446.

Setyorini. (2020). Pandemi Covid-19 dan Online Learning: Apakah Berpengaruh Terhadap Proses Pembelajaran Pada Kurikulum 13?. Journal Of Industrial Enggineering \& Management Research (JEIMAR) 1 (1) 2722-8878.

Sudarsana, K., dkk. (2020). Covid-19 Perspektif Pendidikan. Medan: Yayasan Kita Menulis.

Yusuf, R. A., dan Mukhadis, A. (2018). Model pengembangan Profesionalitas guru sesuai tuntutan Revitalisasi pendidikan Vokasi di Indonesia. Lectura Jurnal Pendidikan. 9 (2): 130-139. 